\title{
Nowe konstrukcje pozycjonerów jako zewnętrznych osi robotów przemysłowych
}

\author{
New functional structures of positioners \\ as outer axes of industrial robots
}

\section{Streszczenie}

Zewnętrzne osie robotów przemysłowych to odrębne maszyny manipulacyjne współdziałające z robotem, sterowane w sposób jak najbardziej zbliżony do osi własnych robota, w tym w oparciu o ten sam program użytkowy. Robotyzacja procesów spawalniczych może wymagać użycia dodatkowych maszyn manipulujących łączonymi elementami. W tym celu mogą być stosowane wszelkiego rodzaju pozycjonery, pełniące funkcję zewnętrznych osi. Oczekuje się od nich dużej nośności i dokładności, a pożądane właściwości użytkowe osiągane są m.in. dzięki odpowiedniej strukturze kinematycznej oraz właściwościom układów napędowych i sterowania. ZAP Robotyka, wspólnie z Zakładem Inżynierii Spajania Politechniki Warszawskiej od szeregu lat prowadzi wspólne prace badawczo - rozwojowe i wdrożeniowe w dziedzinie urządzeń do automatyzacji i robotyzacji procesów technologicznych. W artykule przedstawiono efekty ostatnich prac, związanych z budową i wdrożeniem dwóch nowych typów pozycjonerów.

Słowa kluczowe: pozycjoner, robot spawalniczy, zewnętrzna oś robota

\section{Abstract}

Outer axes of industrial robots is to be defined as independent machines of the entire robotic installation. They are usually controlled in the similar manner based on the same software as the robot axes. Automation of a particular welding process may require the use of auxiliary machines that manipulate the works to be joined. This can be done with the use of various kinds of positioners as outer axes of the robot. They should fulfill such requirements as carrying capacity and accuracy depended on their kinetic structure, drive and control systems. ZAP Robotyka and Welding Engineering Division of Warsaw University of Technology carried on research and development activities within the area of automation of manufacturing processes with the use of industrial robots. The results of new projects being implemented to industry are presented here.

Keywords: positioner, welding robot, external robot axis

\section{Wstęp}

Konieczność szybkiego reagowania na zmieniające się potrzeby współczesnego rynku wymuszają częstą modernizację i zmiany wyrobów produkowanych przy szerokim wykorzystaniu elastycznych środków wytwórczych, w tym robotów przemysłowych. Wysoka elastyczność robotów powinna iść w parze z elastyczną konfiguracją i wyposażeniem stanowisk produkcyjnych. Dotyczy to również tzw. zewnętrznych osi robotów, rozumianych jako odrębne maszyny manipulacyjne współdziałające $z$ robotem, w tym sterowane z poziomu tego samego programu użytkowego, a nawet układu sterowania (kontrolera) [3,5]. Do tej grupy maszyn zaliczamy m.in. pozycjonery manipulujące zamocowanymi na nich przedmiotami spawanymi, a także tory jezdne czy ruchome wysięgniki, zapewniające robotom lokomocję $[1 \div 3,5,7,9]$.

Wraz ze zmieniającą się produkcją, konieczna może okazać się każdorazowa wymiana pozycjonera, jego radykalna przebudowa lub zastosowanie droższego, ale bardziej uniwersalnego urządzenia, np. o większej nośności, zakresie ru-

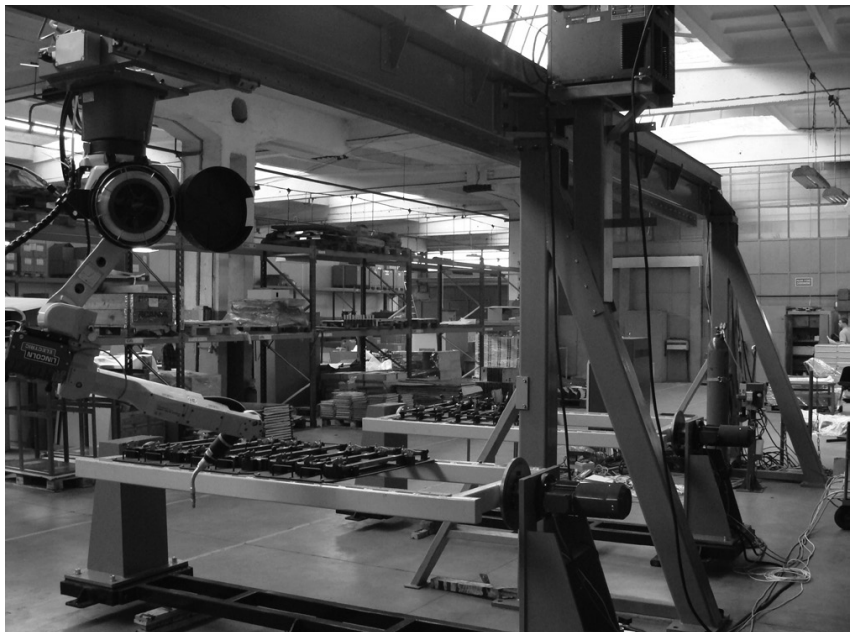

Rys. 1. Robot spawalniczy podwieszony na liniowym torze jezdnym współpracujący z dwoma pozycjonerami wrzecionowymi (ZAP Robotyka)

Fig. 1. Welding installation with a robot underslung on linear track co-acting with two spindle positioners (ZAP Robotyka)

Dr inż. Paweł Cegielski, prof. dr hab. Andrzej Kolasa - Zakład Inżynierii Spajania Politechniki Warszawskiej, dr inż. Tadeusz Sarnowski - ZAP - Robotyka. 
chu czy liczbie stopni swobody (osi manipulacji). Aby sprostać nowym wyzwaniom, ich projektowanie i eksploatacja wymaga innowacyjnego wykorzystania tradycyjnej wiedzy z zakresu konstrukcji maszyn, elektroniki i elektrotechniki, automatyki i programowania.

Pozycjonery stanowią bardzo liczną grupę urządzeń do manipulowania przedmiotami mocowanymi do stołu roboczego za pośrednictwem specjalnego oprzyrządowania i znajdują zastosowanie przy zautomatyzowanym montażu jako zasobniki części do dalszej obróbki itp., głównie jednak wykorzystywane są podczas spawania i procesów pokrewnych. Stosowane są zarówno podczas spawania ręcznego, zmechanizowanego, jak i zautomatyzowanego czy zrobotyzowanego $[1 \div 3,5,7,9]$.

Już jednoosiowa manipulacja mająca miejsce w obracającym się stole pozycjonera może przynieść istotne korzyści technologiczne (optymalizacja pozycji spawania, ruch roboczy przedmiotu podczas procesu) i ekonomiczne (zwiększenie jakości i wydajności). Na potrzeby stanowisk zrobotyzowanych wykonywane są pozycjonery o wielu sterowanych osiach (w praktyce od 1 do 4), w tym ze sterowaniem pozwalającym na realizację ruchów roboczych, także równoczesnych z ruchem robota. Stosowane są także konstrukcje symetryczne - dwustanowiskowe (łącznie do nawet 9 osi), umożliwiające równoczesną i bezkolizyjną pracę robota po jednej stronie i operatora (załadunek i rozładunek) po drugiej.

Najważniejsze parametry pozycjonerów, istotne z punktu widzenia budowy i wykorzystywania, to $[1 \div 3,5,7,9]$ :

- struktura kinematyczna rozumiana jako liczba (dla dwustanowiskowych od 1 do 9, w praktyce jednak nie więcej niż 5) i rodzaj osi manipulacji (obrotowe, liniowe) oraz ich wzajemna konfiguracja (tabl. I),

- rodzaj ruchów poszczególnych osi (ustawcze, robocze) i ich zakres (liniowy, kątowy),

- zakres sterowanych prędkości poszczególnych ruchów,

- nośność i maksymalne momenty obciążające,

- powtarzalność pozycjonowania (podobnego rzędu co robot, a nie gorsza niż +/- 0,5 mm),

- napęd (pneumatyczny, hydrauliczny, elektryczny) i sterowanie ruchem (dyskretne, ciągłe typu serwo oraz hybrydowe - wewnętrznie programowane [5]),

- wymiary, masa i zasilanie pozycjonera.

Wśród wskazanych parametrów, na szczególną uwagę zasługuje możliwość swobodnego programowania dowol- nych pozycji dla wybranych osi manipulacji (ruchy ustawcze), przede wszystkim ruchu roboczego w trakcie spawania, w tym równoczesnego z ruchami samego robota. Tego typu synchronizacja praktycznie wyklucza stosowanie pozycjonerów (ich zespołów napędowych) pochodzących od dostawców niezależnych od producenta robota.

W artykule przedstawiono efekty ostatnich prac, związanych z opracowaniem, budową i wdrożeniem dwóch nowych typów pozycjonerów.

\section{Idee organizacyjne stanowisk zrobotyzowanego spawania}

Podczas konfiguracji zrobotyzowanych stanowisk spawalniczych uwarunkowania techniczne, technologiczne i funkcjonalne w dużej mierze sprowadzać się będą do ustalenia relacji organizacyjnych pomiędzy robotem, a określonym typem pozycjonera lub pozycjonerów $[3,8]$. Elementem uzupełniającym konfigurację, często nie mniej ważnym, może być układ jezdny, realizujący lokomocję robota. Można przy tym wskazać następujące, główne warianty:

- Robotipozycjonerjednostanowiskowy(rys. 2a). Rozwiązaniepodstawowe, wymagające naprzemiennej pracy robota i obsługi (ładowanie i rozładowanie) oraz specjalnych zabezpieczeń (operator funkcjonujący w przestrzeni maksymalnej robota), o najniższym współczynniku jarzenia łuku (z uwagi na przestoje w pracy robota).

- Robot i pozycjoner dwustanowiskowy. Równoczesna praca robota po jednej i operatora dokonującego przeładunku po drugiej stronie, z wysokim poziomem bezpieczeństwa (praca operatora poza zasięgiem robota i możliwość zainstalowania sztywnego ekranu pomiędzy stanowiskami) i wysokim współczynnikiem jarzenia łuku. Typowe pozycjonery dwustanowiskowe:

- Z pionową osią główną zmiany stanowisk utworzonych na powierzchni pojedynczego stołu roboczego, zwykle o znacznej średnicy, i przedzielonego sztywną przegrodą na dwie lub więcej części (najczęściej nie więcej niż cztery). Rozwiązanie o najmniejszej funkcjonalności z uwagi na brak jakiejkolwiek manipulacji technologicznej zamocowanych elementów (jedynie zmiana stanowisk roboczych). Do zalet zaliczyć można prostotę sterowania (zwykle dyskretnego - podziałowego) oraz możliwość

Tablica I. Zestawienie właściwości manipulacyjnych układów kinematycznych pozycjonerów $[1 \div 3]$

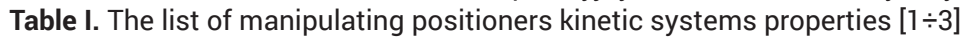

\begin{tabular}{|c|c|c|c|}
\hline Cel manipulacji & Rodzaj manipulacji & Zakres manipulacji & Sposób realizacji \\
\hline \multirow{7}{*}{$\begin{array}{l}\text { orientowanie przedmiotu } \\
\text { (zmiana jego kątowego } \\
\text { ustawienia w przestrzeni) }\end{array}$} & \multirow{2}{*}{$\begin{array}{l}\text { ustawienie stołu roboczego } \\
\text { wokół własnej osi }\end{array}$} & stałe & - \\
\hline & & zmienne & obrót wokół własnej osi \\
\hline & \multirow{5}{*}{$\begin{array}{l}\text { ustawienie kątowe osi obrotu } \\
\text { stołu roboczego }\end{array}$} & \multirow{2}{*}{ stałe } & oś ustawiona pionowo \\
\hline & & & oś ustawiona poziomo \\
\hline & & \multirow{2}{*}{$\begin{array}{l}\text { zmienne - w jednej } \\
\text { płaszczyźnie }\end{array}$} & $\begin{array}{c}\text { pochylenie obustronnie } \\
\text { podpartego stołu }\end{array}$ \\
\hline & & & $\begin{array}{c}\text { obrót ramienia (wysięgnika) } \\
\text { stołu }\end{array}$ \\
\hline & & $\begin{array}{l}\text { zmienne - w dwu } \\
\text { płaszczyznach }\end{array}$ & $\begin{array}{l}\text { pochylenie stołu } \\
\text { i obrót ramienia }\end{array}$ \\
\hline \multirow{3}{*}{$\begin{array}{l}\text { pozycjonowanie przedmiotu } \\
\text { (przemieszczanie liniowe) }\end{array}$} & \multirow{3}{*}{$\begin{array}{l}\text { zmiana wysokości położenia } \\
\text { stołu roboczego }\end{array}$} & stała & - \\
\hline & & \multirow{2}{*}{ zmienna } & pochylenie ramienia stołu \\
\hline & & & przesuw liniowy ramienia stołu \\
\hline
\end{tabular}


równoczesnej pracy na każdym z gniazd utworzonych na powierzchni stołu (rys. 2b).

- Rozwiązanie o właściwościach użytkowych jak poprzednio, ale w miejsce pojedynczego stołu szereg nieruchomych stołów (zwykle od 2 do 4) złączonych wspólną, obrotową ramą i przedzielonych sztywnymi przegrodami.

- Z pionową osią główną zmiany dwóch niezależnych (kinematycznie, sterowaniem i napędem) stanowisk - stołów roboczych (rys. 2c). Rozwiązanie uniwersalne, pozwalające na wieloosiową manipulację zamocowanych przedmiotów, zwykle jednak o ograniczonym ciężarze i rozmiarze. Wyjątek stanowi pozycjoner utworzony z dwóch par stołów roboczych ustawionych w układzie wrzecionowym ( $w$ formie litry $\mathrm{H}$, rys. 3a).

- Pozycjoner z poziomą osią zmiany stanowisk roboczych, utworzony na bazie dwóch par stołów ustawionych w układzie wrzecionowym (rys. 3b). Oś zmiany stanowisk może być dodatkowo wykorzystana do manipulacji, np. zmiany wysokości spawanych przedmiotów względem robota.

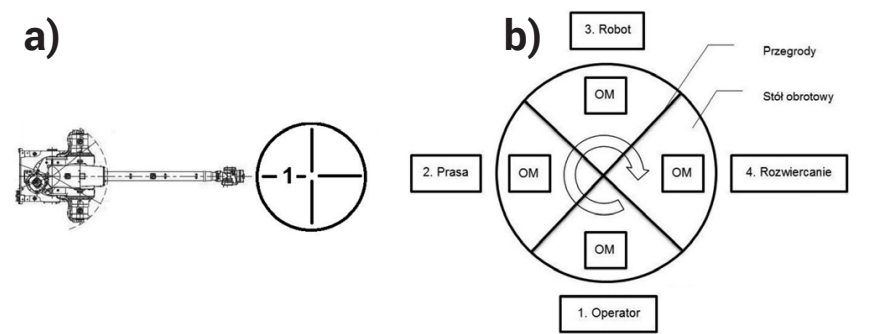

c)

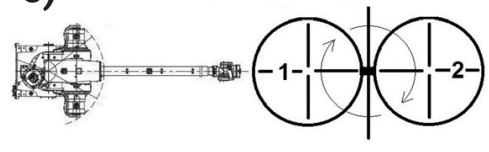

d)



Rys. 2. Schematy wybranych konfiguracji robot - pozycjoner. a) jednostanowiskowy, b) z gniazdami utworzonymi na powierzchni stołu, obsługiwanymi równocześnie po każdym obrocie o $90^{\circ}$ (OM oprzyrządowanie mocujące) [3,9], c) dwustanowiskowy, d) z dwoma pozycjonerami jednostanowiskowymi

Fig. 2. Examples of the robot - positioner configuration: a) single stand, b) turning table with four working cells being simultaneously operated after every movement of $90 \mathrm{deg}$ (OM - fixing equipment), c) double stand, (d) with two single stand positioners

a)

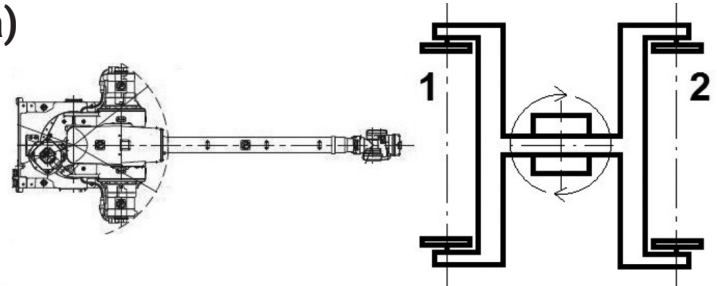

b)



Rys. 3. Schematy wybranych konfiguracji robot - pozycjoner dwustanowiskowy w układzie wrzecionowym, z osią główną zmiany stanowisk: a) pionową w układzie $\mathrm{H}, \mathrm{b}$ ) poziomą

Fig. 3. Examples of the robot - double stand spindle positioner configuration with the main axle of the working stand: a) vertical $\mathrm{H}$ shape, b) horizontal
- Robot i dwa (lub więcej) pozycjonery jednostanowiskowe (rys. 2d). Rozwiązanie stosowane przy braku odpowiednich pozycjonerów dwustanowiskowych. Dwa pozycjonery stojące obok siebie lub ustawione wokół robota mogą stanowić funkcjonalną alternatywę pozycjonera dwustanowiskowego, np. w przypadku bardzo dużych i/lub ciężkich przedmiotów, niemożliwych do zainstalowania na zwykle mniejszych jednostkach dwustanowiskowych.

- Jak poprzednio, ale z pozycjonerami dwustanowiskowymi, dla jeszcze większego zwiększenia funkcjonalności stanowiska, np. realizacji dwóch różnych zadań lub większej wydajności.

- Robot na torze jezdnym i dwa pozycjonery, np. wrzecionowe, ustawione wzdłuż trasy jego przejazdu (rys. 4). Rozwiązanie stosowane w przypadku bardzo dużych (długich) przedmiotów przy braku odpowiednich pozycjonerów dwustanowiskowych lub ograniczonej przestrzeni produkcyjnej.

- Robot i ...dodatkowy robot w roli pozycjonera podczas spawania najbardziej złożonych, jednak lżejszych przedmiotów. Obok wieloosiowej manipulacji, robot - pozycjoner może spełniać dodatkowe funkcje transportowe lub obsługowe, w tym pobieranie i odkładanie zespołów spawanych.

Przedstawione, podstawowe warianty organizacyjne oparte na zestawieniu robot - pozycjoner w praktyce mogą być jeszcze bardziej zróżnicowane, m.in. z uwagi na specyficzne układy kinematyczne i specjalistyczne wykonanie pozycjonerów.

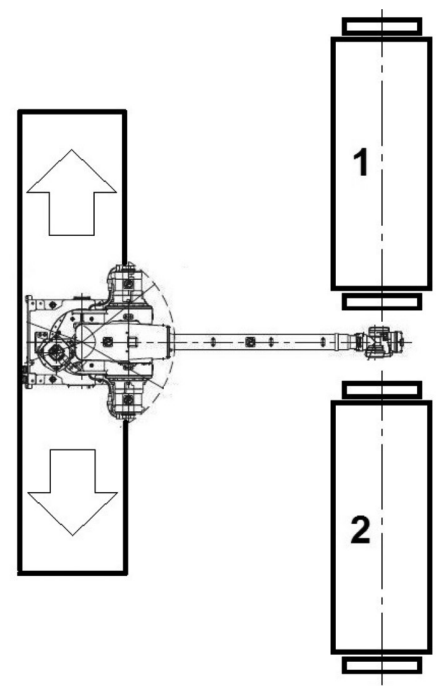

Rys. 4. Schemat konfiguracji stanowiska z robotem spawalniczym na liniowym torze jezdnym $z$ dwoma pozycjonerami wrzecionowymi Fig. 4. Examples of the working stand organization with welding robot on linear track and two spindle positioners

\section{Idea nowych pozycjonerów}

Wysoka funkcjonalność i elastyczność zrobotyzowanych systemów spawalniczych wymaga aby nie tylko robot, ale także pozostałe urządzenia instalacji odznaczały się wysokimi walorami użytkowymi. W odniesieniu do pozycjonerów zwracają obecnie uwagę wieloosiowe konstrukcje dwustanowiskowe (symetryczne), pozwalające na roboczą manipulację zamocowanych przedmiotów (także równocześnie z ruchami robota), zarówno konwencjonalne - oparte na zamocowanych przegubowo płaskich stołach montażowych (rys. 2c), jak i ze stołami w układzie wrzecionowym (rys. 3). W ramach omawianych prac opracowano i wdrożono dwie nowe koncepcje pozycjonerów wpisujące się w aktualne tendencje konstrukcyjne i funkcjonalne. 
Pierwszą, nową konstrukcją jest pięcioosiowy pozycjoner dwustanowiskowy (symetryczny) z płaskimi stołami montażowymi. Każdy ze stołów posiada dwie niezależne osie manipulacji - obrotu i pochylenia. Oś główna zmiany stanowisk roboczych - pionowa, realizuje obrót pozycjonera w płaszczyźnie poziomej (rys. 5).

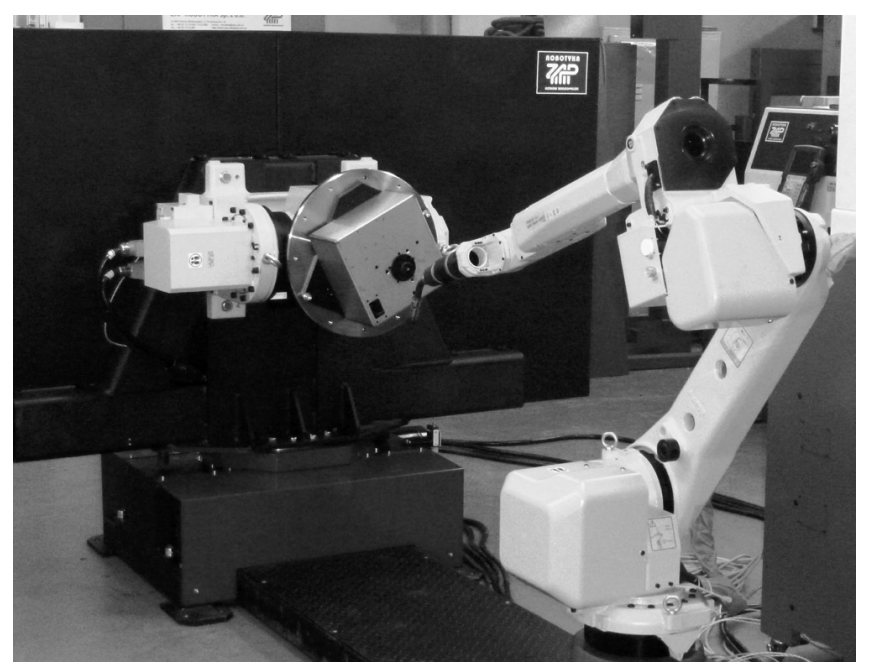

Rys. 5. Pięcioosiowy pozycjoner dwustanowiskowy symetryczny (ZAP Robotyka)

Fig. 5. The 5-axes double stand symmetric positioner (ZAP Robotyka)

Zastosowana, dodatkowa manipulacja obrotowym stołem pozycjonera - pochylająca jego oś, jest konieczna do realnej zmiany orientacji przestrzennej spawanych elementów. Z uwagi na założone sterowanie ciągłe osiami obrotu i pochylenia obydwu stołów i współpracę z robotami FANUC, do opracowania i budowy pozycjonera wytypowano dwa gotowe, dwuosiowe zespoły pozycjonujące tej firmy, opatrując je specjalnie opracowaną ramą z mechanizmem obrotowym, przesłonami itp. Wykorzystana jednostka pozycjonująca realizuje pochylenie poprzez obrót obustronnie podpartego zespołu stołu. Taka konstrukcja, w odróżnieniu od stołów pochylanych za pośrednictwem obrotowego ramienia, odznacza się zwykle mniejszym zakres ruchu przy jednocześnie znacznie wyższej sztywności i nośności. Innowacyjność prezentowanego rozwiązania polegała na specyficznym usytuowaniu obydwu zespołów napędowych względem wspólnej, obrotowej ramy. Podstawy pozycjonerów zamocowano bowiem do pionowej przegrody (odpowiednio w tym miejscu wzmocnionej) niejako w pozycji naściennej. Dzięki temu, uzyskany efektywny zakres pochylenia stołu osiągnął 2700 , w tym możliwe jest jego ustawienie w pozycjach poziomej, poprzez pionową do poziomej, ale odwróconej. Wysokość, na jakiej zamocowano zespoły napędowe dobrano na drodze symulacji komputerowej 3D w odniesieniu do przestrzeni roboczej typowych robotów spawalniczych firmy FANUC oraz przewidywanych zadań produkcyjnych. Dodatkowa, piąta oś realizuje ustawczy obrót $n \times 1800$ służący zmianie stanowisk roboczych. W tablicy II zestawiono główne parametry użytkowe pozycjonera.

Kolejną, nową konstrukcją jest trzyosiowy pozycjoner dwustanowiskowy (symetryczny) ze stołami montażowymi w układzie wrzecionowym (po dwa stoły ustawione naprzeciw siebie) i poziomą osią główną zmiany stanowisk roboczych. Stanowiska robocze przedzielono sztywnym ekranem, chroniącym operatora i osoby postronne przed szkodliwym działaniem procesu (rys. 6).

Prezentowany pozycjoner jest autorskim opracowaniem wykorzystującym najnowsze tendencje w dziedzinie projektowania i eksploatacji tej grupy maszyn. Przewidziano w nim m.in. sterowanie ciągłe, pozwalające na manipulację spawanymi przedmiotami równocześnie z ruchami robota oraz osie obrotowe z wydrążonymi otworami przelotowymi do swobodnego przeprowadzenia kabli masowych, zasilających i sterujących oprzyrządowaniem technologicznym itp. W odróżnieniu od wcześniej omówionego pozycjonera pięcioosiowego jest to konstrukcja uniwersalna, dostosowana do montażu zespołów napędowych (silnik, czujniki, przekładnia) pochodzących od większości producentów robotów, a także jednostek uniwersalnych, będących wcześniejszym wspólnym opracowaniem autorów [5].

Tablica II. Parametry użytkowe nowego, pięcioosiowego pozycjonera dwustanowiskowego

Table II. Working parameters of the new 5 -axes double stand positioner

\begin{tabular}{|c|c|}
\hline Nazwa parametru & Wartość i jednostka \\
\hline Liczba osi & 5 \\
\hline Nośność (na stronę) & $500 \mathrm{~kg}$ \\
\hline $\begin{array}{c}\text { Powtarzalność } \\
\text { pozycjonowania }\end{array}$ & $\pm 0,1 \mathrm{~mm}$ \\
\hline $\begin{array}{c}\text { Maksymalna prędkość } \\
\text { obrotu stołu J1 }\end{array}$ & $120^{\circ} / \mathrm{s}$ \\
\hline $\begin{array}{c}\text { Maksymalna prędkość } \\
\text { pochylenia stołu J2 }\end{array}$ & $190^{\circ} / \mathrm{s}$ \\
\hline $\begin{array}{c}\text { Zakres ruchu obrotu stołu } \\
\text { J1 }\end{array}$ & $270^{\circ}$ \\
\hline $\begin{array}{c}\text { Zakres ruchu pochylenia } \\
\text { stołu J2 }\end{array}$ & $480^{\circ}$ \\
\hline $\begin{array}{c}\text { Zakres obrotu osi głównej } \\
\text { (zmiany stanowisk) }\end{array}$ & \\
\hline
\end{tabular}

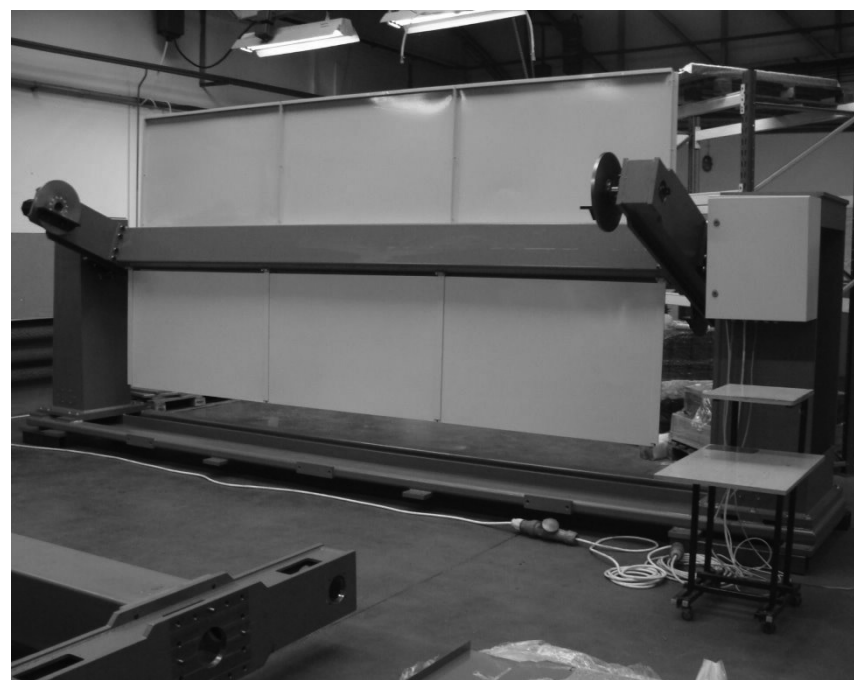

Rys. 6. Trzyosiowy pozycjoner dwustanowiskowy (symetryczny) w układzie wrzecionowym (ZAP Robotyka)

Fig. 6. The 3-axes double stand symmetric spindle positioner (ZAP Robotyka) 
Prezentowania konstrukcja oparta na trzech równoległych osiach pozwala na ustalenie wysokości, na jakiej będą się znajdowały stanowiska. Dla zapewnienia najwyższej sztywności i dokładności, obrotowe ramię mechanizmu zamieniającego stanowiska jest dodatkowo blokowane mechanicznie w ustalonym położeniu. Prezentowany pozycjoner opracowano i wdrożono w dwóch rozmiarach, o nośnościach 250 i 500 kg na każdą ze stron (tabl. III).

Tablica III. Parametry użytkowe nowego, trzyosiowego pozycjonera dwustanowiskowego

Table III. Working parameters of the new 3-axes double stand positioner

\begin{tabular}{|c|c|c|}
\hline \multirow{2}{*}{ Nazwa parametru } & \multicolumn{2}{|c|}{ Wartość i jednostka } \\
\cline { 2 - 3 } & Wersja 250 & Wersja 500 \\
\hline Liczba osi & 3 & 3 \\
\hline $\begin{array}{c}\text { Nośność (na stronę) } \\
\text { obciążeń między stanowi- } \\
\text { skami }\end{array}$ & $250 \mathrm{~kg}$ & $500 \mathrm{~kg}$ \\
\hline $\begin{array}{c}\text { Rozstaw tarcz pozycjonera } \\
\text { Powtarzalność } \\
\text { pozycjonowania }\end{array}$ & $2200 \mathrm{~mm}$ & $2200 \mathrm{~mm}$ \\
\hline $\begin{array}{c}\text { Maksymalna prędkość } \\
\text { obrotu stołu }\end{array}$ & 0,4 obr/sek. & 0,4 obr/sek. \\
\hline $\begin{array}{c}\text { Zakres ruchu obrotu stołu } \\
\text { Makg }\end{array}$ & $\mathrm{n} \times 360^{\circ}$ & $\mathrm{n} \times 360^{\circ}$ \\
\hline $\begin{array}{c}\text { Zakres obrotu osi głównej } \\
\text { (zmiany stanowisk) }\end{array}$ & $\mathrm{n} \times 180^{\circ}$ & $\mathrm{n} \times 180^{\circ}$ \\
\hline $\begin{array}{c}\text { Maksymalny czas zmiany } \\
\text { stanowisk (obrotu o 180 }\end{array}$ & $10 \mathrm{sek}$. & $10 \mathrm{sek}$. \\
\hline
\end{tabular}

\section{Modelowanie konstrukcyjne i badania użytkowe}

Wzorem poprzednich opracowań autorów niniejszego opracowania [4-6], na etapie projektowania obydwu pozycjonerów wykonano szereg funkcjonalnych modeli 3D w środowisku CAD, (rys. 7, 8) oraz analiz z użyciem metody elementów skończonych MES. Na tej podstawie możliwe było sprawdzenie poszczególnych wariantów konstrukcyjnych, dobranie właściwych zespołów mechanicznych, a także ustalenie najlepszych parametrów geometrycznych pod kątem typowych zadań spawalniczych oraz właściwości współpracujących maszyn. Uwzględniono m.in. przestrzenie robocze typowych robotów spawalniczych, w tym ich zasięg poziomy (maksymalny promień przestrzeni roboczej), typowo zawierający się w przedziale 1400-2100 mm.

W celu rozwiązania niektórych zagadnień konstrukcyjnych posłużono się także prostym modelowaniem metodą elementów skończonych MES. Dotyczyło to np. doboru geometrii wałów osi głównej pozycjonera trzyosiowego, służącej do zmiany stanowisk. Z uwagi na konieczność przeprowadzenia kabli zasilających, sterujących i masowych, w wałach wykonano przelotowe otwory. Stwierdzono, że niezależnie od przyjętych warunków obciążenia, największa koncentracja naprężeń (ścinających i skręcających) występuje na wale o pierwotnie założonej średnicy $\varnothing 75$ z wewnętrznym otworem przelotowym $\emptyset 26$. Drugi z wałów osi głównej, miał pierwotnie założoną średnicę $\emptyset 120$ z wewnętrznym otworem przelotowym Ø80. Różnica w średnicach obydwu wałów wynikała z obecności przekładni po stronie wału mniejszego. Dodatkowo, nadmierne obciążenie wału o mniejszej średnicy wynikało z niesymetrycznego rozłożenia obciążenia - mniejszy wał obciążany był na długości $74 \mathrm{~mm}$, a większy $35 \mathrm{~mm}$. W wyniku przeprowadzonego modelowania skorygowano geometrię obydwy wałów, typu przekładni itp. Poprawność przeprowadzonych badań pozytywnie zweryfikowano podczas prób ruchowych zbudowanego pozycjonera.

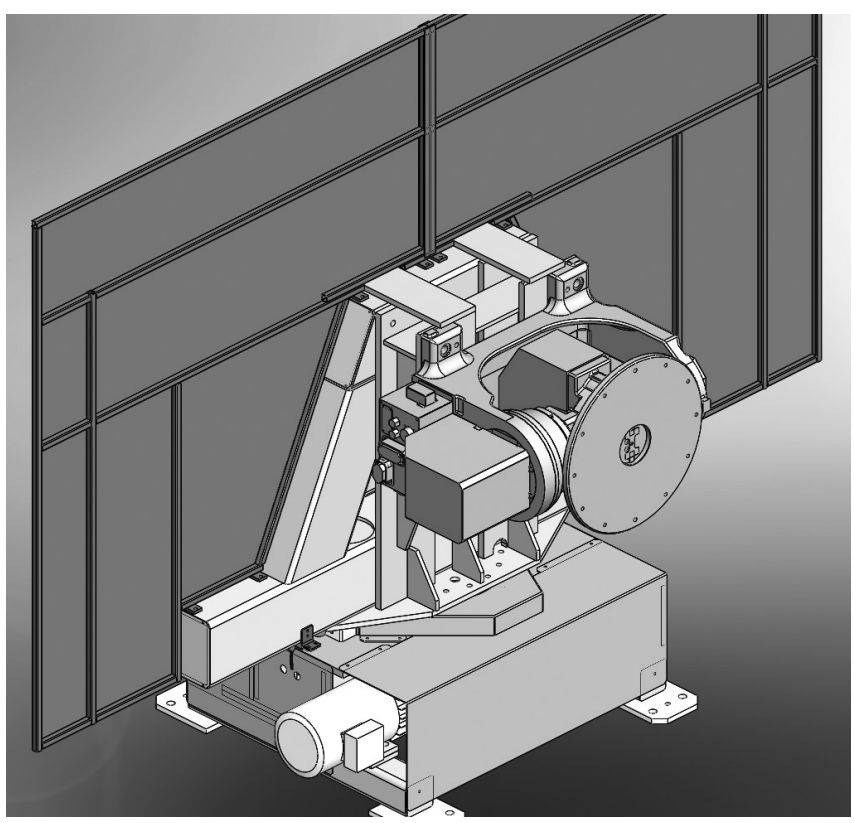

Rys. 7. Modelowanie CAD 3D podczas projektowania pozycjonera pięcioosiowego

Fig. 7. The design of 3D CAD modelling of 5-axes positioner

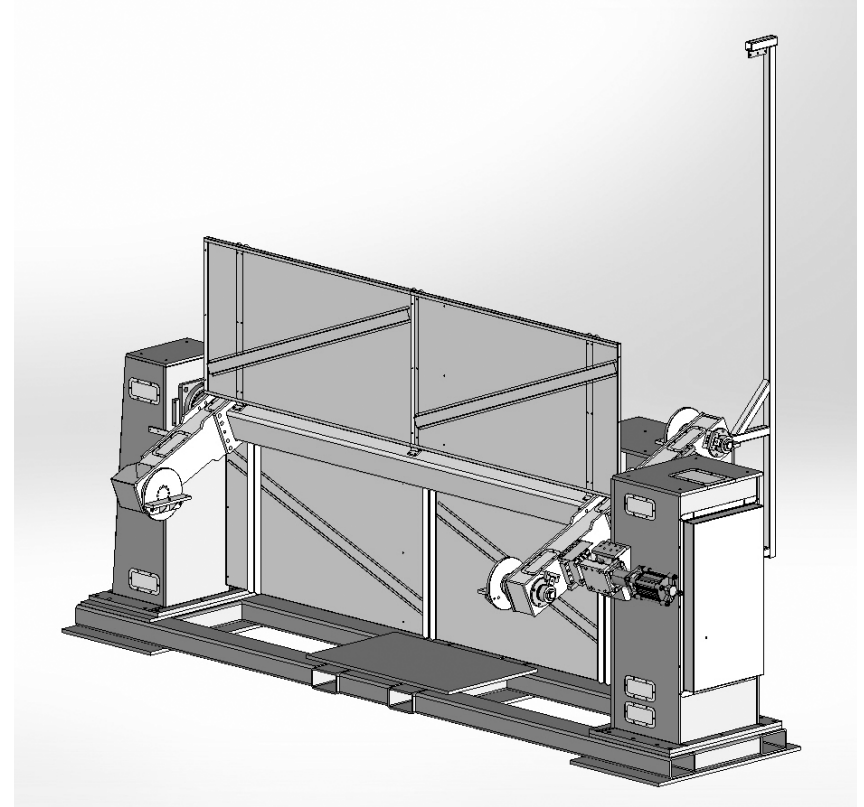

Rys. 8. Modelowanie CAD 3D podczas projektowania pozycjonera trzyosiowego

Fig.8. The design of 3D CAD modelling of 3-axes positioner 


\section{Podsumowanie}

Przedstawione urządzenia powstały w oparciu o oryginalne projekty, zakładające wykorzystanie najnowszych układów mechanicznych i napędowych. Z drugiej strony, uwzględniają potrzeby i możliwości potencjalnych, głównie krajowych użytkowników, zarówno pod względem ceny jak i oferowanych możliwości technicznych i technologicznych oraz uniwersalności.

Zaproponowana konfiguracja pozycjonera pięcioosiowego pozwala na realizację złożonych i precyzyjnych zadań spawalniczych. Jedną z pierwszych aplikacji było niezwykle trudne spawanie metodą TIG cienkościennych konstrukcji przestrzennych.

Pozycjonery o konstrukcji wrzecionowej należą do najbardziej uniwersalnych. Z jednej strony pozwalają na manipulację przedmiotami długimi, których środek ciężkości jest znacznie oddalony od miejsca zamocowania (rury, wały itp.), a z drugiej, przedmiotami zamocowanymi za pośrednictwem pośredniej ramy, umieszczanej pomiędzy stołami. Zaproponowany pozycjoner wrzecionowy z poziomą osią główną zmiany stanowisk roboczych, w odróżnieniu od pozycjonerów wrzecionowych w układzie $\mathrm{H}$ (z pionową osią zmiany stanowisk), wymaga znacznie mniejszej przestrzeni oraz pozwala sterować wysokością, na jakiej znajdować się będą stoły po stronie robota i obsługi.

\section{Literatura}

[1] Cegielski P. Koncepcja klasyfikacji pozycjonerów do spawania zrobotyzowanego. Przegląd Spawalnictwa 2/1993, str. 7-10.

[2] Cegielski P. Optymalny wybór pozycjonerów do stanowisk spawania zautomatyzowanego. Technologia i Automatyzacja Montażu, str. 46-48, 2/1993.

[3] Cegielski P. Rozdziały: 7.2.1 Pozycjonery spawalnicze, 7.4.3 Zewnętrzne osie. W: Technika spawalnicza w praktyce. Poradnik inżyniera konstruktora i technologa. Red. K. Ferenc. Warszawa, Verlag Dashofer 2015.

[4] Cegielski P., Golański D., Kolasa A., Sarnowski T. Modelowanie i wdrożenie wysięgników do lokomocji robotów przemysłowych. Przegląd Spawalnictwa $1 / 2015$, str. 6-13.

[5] Cegielski P., Kolasa A., Sarnowski T. Pozycjonery i tory jezdne - nowe rozwiązania zewnętrznych osi robotów przemysłowych. Prace Naukowe. Elektronika, z.166. OW Politechniki Warszawskiej, 2008, str. 357-366.

[6] Golański D., Cegielski P., Giżyński P., Kolasa A. Modelowanie numeryczne ugięcia podstawy robotów przemysłowych. Przegląd Spawalnictwa 6/2014, str. 34-41.

[7] Honczarenko J. Roboty przemysłowe. Budowa i zastosowanie. WNT Warszawa 2011.

[8] Kruczyński M. Zrobotyzowane stanowiska spawalnicze - przykłady konfiguracji. Biuletyn Automatyki 3/2008, ASTOR, str. 20-22

[9] Żurek J. i inni: Podstawy robotyzacji. Laboratorium. Wydawnictwo Politechniki Poznańskiej, Poznań 2004. 